\section{PENANAMAN NILAI- NILAI PANCASILA DENGAN MEDIA KOMIK PANCASILA (KOPALA) DI PESANTREN YATIM CAHAYA MADINAH TANGERANG}

\author{
Dyana Ayundasari', Aulia Rahmah², \\ Dedek Putra Bungsu ${ }^{3}$ Feri \\ Agustiawan ${ }^{4}$, Pety Tanjung Sari ${ }^{5}$, \\ Chandra Fitra Arifianto6* \\ 1,2,3,4,5,6 Universitas Pamulang \\ *Chandra Fitra Arifianto \\ Email : dosen0II77@unpam.ac.id
}

\begin{abstract}
Today is the understanding of the values of Pancasila in the younger generation is getting eroded. Of course, it is hoped that this will not happen to young santri. With a solid Islamic background, santri find it easier to understand the values of Pancasila and do not fall into a negative understanding of Pancasila. Therefore, this community service activity aims to provide a new understanding of the use of visual media in the form of the Pancasila Comic (abbreviated as KOPALA). In realizing this goal, the methods used are lectures and evaluation using games by utilizing devices that can display comic visuals. At the same time, the participants who were included in this activity were the santri, who were also students at the Madrasah Ibtidaiyah and Madrasah Tsanawiyah benches, totalling 17 santri. They are santri of Pesantren Yatim Cahaya Madinah in South Tangerang. In general, the implementation of the activities was successful although with some shortcomings, such as facilities. Furthermore, it is necessary to apply the same action to adolescents at the Madrasah Aliyah level and training for teachers in literacy, software and hardware, gadgets, and classroom management. Keywords: Pancasila Comics; Santri; Visual Learning
\end{abstract}

\begin{abstract}
Abstrak
Dewasa ini pemahaman terhadap nilai-nilai Pancasila pada generasi muda semakin terkikis. Hal ini tentu saja diharapkan tidak terjadi juga pada santrisantri muda. Dengan latar belakang agama Islam yang kuat, santri dirasa lebih mudah dalam memahami nilai-nilai Pancasila dan tidak turut terperosok dalam pemahaman negatif terhadap Pancasila. Oleh karenanya, kegiatan pengabdian kepada masyarakat ini bertujuan untuk memberikan pemahaman baru atas penggunaan media visual, berupa Komik Pancasila (KOPALA). Dalam merealisasikan tujuan tersebut, metode yang digunakan adalah ceramah dan evaluasi menggunakan permainan dengan memanfaatkan piranti yang dapat menampilkan visual komik. Sedangkan peserta yang diikutkan pada kegiatan ini adalah para santri yang juga merupakan peserta didik di bangku Madrasah Ibtidaiyah dan Madrasah Tsanawiyah, yang berjumlah 17 orang. Mereka merupakan santri Pesantren Yatim Cahaya Madinah di Tangerang Selatan. Secara umum, pelakasanaan kegiatan berhasil meskipun dengan beberapa kekurangan, seperti fasilitas. Selanjutnya, perlu diberlakukan tindakan yang sama pada remaja setingkat Madrasah Aliyah dan pelatihan bagi pengajar pada aspek literasi, penggunaan piranti lunak maupun keras, gawai serta manajemen kelas. Kata Kunci: Komik Pancasila; Santri; Pembelajaran Visual
\end{abstract}


Penanaman Nilai-Nilai Pancasila dengan Media Komik Pancasila (KOPALA) di Pesantren Yatim Cahaya Madinah Tangerang

Dyana Ayundasari, Aulia Rahmah, Dedek Putra Bungsu, Feri Agustiawan, Pety Tanjung Sari, Chandra Fitra Arifianto

Vol. 1, No. 2, Agustus 2021 hal. 116-122

DOI Artikel : 10.46306/jub.v1i2.22

\section{PENDAHULUAN}

Guru sangatlah berperan sangat penting dalam ranah pendidikan, terlebih lagi dalam proses pembelajaran di dalam kelas maupun praktik. Dalam menjalankan tugasnya tersebut, guru diharapkan selalu berupaya memikirkan meningkatkan kualitas pembelajaran yang diampunya. Beberapa tindakan yang perlu disiapkan diantaranya menyusun perencanaan pembelajaran dengan seksama lalu juga menyiapkan sejumlah perangkat pembelajaran yang tepat guna dengan apa yang akan disampaikannya kepada para peserta didik. Namun yang tidak kalah pentingnya ialah guru dituntut untuk dapat meningkatkan kualitas pembelajaran dengan menciptakan keefektifan kondisi pembelajaran.

UU Sistem Pendidikan Nasional (Sisdiknas) No 20 tahun 2003 pasal 40 ayat 2 mengamanatkan pada pendidik (guru) untuk turut serta dalam menciptakan suasana pendidikan yang bermakna, menyenangkan, kreatif, dinamis, dan dialogis. Implementasi dari apa yang dimandatkan tersebut, guru hendaknya tidak hanya menggunakan metode ceramah dalam menjalankan pembelajaran kepada peserta didiknya karena dapat melahirkan kebosanan pada diri peserta didik, yang berdampak peserta didik tidak memahami apa yang disampaikan oleh guru tersebut. Meskipun begitu, Savira dkk. (2018) menilai bahwa metode ceramah interaktiflah yang efektif dalam pemberian materi menggunakan ceramah. Namun, ceramah interaktif ini juga perlu didukung penggunaan media agar lebih menarik dan dikatakan 'interaktif itu sendiri. Salah satu penggunaan media yang dapat membantu dalam proses belajar mengajar adalah gawai.

Namun kenyataannya, masih banyak guru yang memberikan materi secara utuh dengan metode ceramah dan peserta didik terpaksa harus menghafal dan menerima materi pelajaran tersebut walaupun tidak dapat membuktikan kebenaran materinya. Kendala lain yang muncul yaitu kurang antusiasme peserta didik dalam mengikuti pembelajaran, sehingga sulitnya melibatkan peserta didik untuk aktif dalam proses pembelajaran tersebut. Ketidakaktifan peserta didik ini perlu untuk dicermati. Kenyataan di lapangan masih banyak ditemukan pemberian materi tanpa adanya kesempatan pada peserta didik untuk mengetahui dan melakukan proses memperoleh ilmu. Hal ini dimungkinkan karena keterbatasan alat peraga, waktu dan kurang aktifnya guru dalam memberikan materi dalam proses pembelajaran. Terlebih saat pemberian materi terkait penanaman nilai-nilai Pancasila. Pujilestari \& Susila (2020) menyebutkan jika media visual mampu menumbuhkan antusiasme peserta didik untuk memahami materi pada Pendidikan Pancasila dan Kewarganegaraan (PPKn) karena mampu memberikan gambaran nyata dari sebuah suatu materi.

Pentingnya pemahaman terhadap nilai-nilai yang ada Pancasila perlu ditanamkan sedari dini. Sebagai bentuk jati diri bangsa, generasi muda harus mampu untuk menghayati dan mengimplementasikannya. Khosiah (2020) menjelaskan jika peserta didik hanya mampu mengahafal sila-sila yang termaktub pada Pancasila, tanpa mengerti pemaknaannya dalam keseharian hidup mereka. Sangatlah miris jika kasus ini akan berlangsung secara berkelanjutan. Hanya saja, pemberian materi terkait Pancasila banyak yang hanya berasal dari kelas dan seringkali membosankan bagi peserta didik. Disinilah peran guru untuk dapat mahir dalam penyampaian materi (Mayanty dkk., 202I).

Namun, kondisi peserta didik yang merupakan santri tentulah berbeda dalam pemberian perlakuan. Penempatan tempat belajar dengan tempat tinggal yang sama dalam satu lokasi menjadikan keseharian mereka hanya berada dalam satu lokasi dan memiliki keterbatasan kehidupan sosial. Setiawan dkk. (2015) menjelaskan adanya beberapa pantangan yang harus diikuti oleh para santri. Salah satunya adalah teknologi. Larangan tersebut dimaksudkan sebagai antisipasi pesantren terhadap penyalahgunaan teknologi. Sebaliknya, di luar pesantren kemajuan teknologi tidak bisa dihadang. Sehingga menurut Rafa'al \& Sangadji (2020) perlu kedewasaan dan kebijaksanaan santri sendiri dalam pemanfaatan teknologi untuk 
Penanaman Nilai-Nilai Pancasila dengan Media Komik Pancasila (KOPALA) di Pesantren Yatim Cahaya Madinah Tangerang

Dyana Ayundasari, Aulia Rahmah, Dedek Putra Bungsu, Feri Agustiawan, Pety Tanjung Sari, Chandra Fitra Arifianto

Vol. 1, No. 2, Agustus 2021 hal. 116-122

DOI Artikel : 10.46306/jub.v1i2.22

belajar dengan pendekatan moderat. Maksudnya ialah teknologi perlu untuk diijinkan dapat digunakan sebatas untuk media pembelajaran, terutama terkait pengamalan nilai-nilai Pancasila, dengan keseimbangan dalam mencernanya.

Dewasa ini, Pancasila masih ada pihak-pihak yang meragukannya. Parahnya lagi, beberapa pihak-pihak tersebut memiliki latar belakang sebagai santri. Inilah yang oleh Hendri dkk. (2018) digambarkan seakan Pancasila bentuk dasar negara yang salah untuk suatu negara dimana mayoritas muslim bermukim. Sehingga diharapkan seorang santri dapat menunjukkan identitasnya sebagai warga negara yang mampu mengejawantahkan Islam ke dalam nilai-nilai Pancasila. Atas dasar gambaran tersebutlah, dirasa kegiatan pengabdian kepada masyarakat (PKM) ini perlu dan urgen untuk dilaksanakan.

\section{METODE PENGABDIAN}

Metode pengabdian yang digunakan ialah presentasi atau ceramah dengan diselingi permainan. Mengingat peserta pada PKM ini ialah para santri yang berada di tingkat Madrasah lbtidaiyah (MI) dan Madrasah Tsanawiyah (MTs), permainan dirasa akan efektif dalam membantu peserta dalam memahami suatu materi. Jumlah peserta yang hadir sebanyak 15 santri dan sepenuhnya mengikuti kegiatan dari awal hingga akhir. Selanjutnya aktivitas observasi dan diskusi juga dilakukan sebagai cara asesmen pemahaman peserta.

\section{PELAKSANAAN DAN PEMBAHASAN}

Pelaksanaan kegiatan pengabdian (PKM) kepada masyarakat ini dilakukan di Yayasan Pesantren Yatim Cahaya Madinah. Sebelum pelaksanaan dilakukan, tim PKM melakukan asesmen kebutuhan yang diperlukan oleh para santri. Kebutuhan yang dirasakan oleh pengurus pesantren ialah antusiasme santri sebagai peserta didik pada mata pelajaran PPKn. Lalu saat tim PKM mengaitkan dengan beberapa kasus terkini yang dilakukan oleh generasi muda, kami bersepakat bahwa perlunya ditanamkan pemahaman terhadap nilai-nilai Pancasila.

Sedangkan pelaksanaannya sendiri dilakukan dua minggu setelah kunjungan tersebut. Pada tanggal 2I Februari 202I, kegiatan PKM dilakukan di aula milik Yayasan Pesantren Yatim Cahaya Madinah yang berlokasi di Pondok Cabe llir, Kecamatan Pamulang, Kota Tangerang Selatan. Rincian kegiatan dapat dilihat pada tabel I. Pemberian materi yang dilakukan menggunakan proyektor yang menampilkan beberapa slide komik Pancasila yang telah dipersiapkan (lihat gambar I).

\begin{tabular}{|l|l|l|}
\hline Waktu & Kegiatan & Penanggung Jawab \\
\hline 09:00 - 09:15 & Pembukaan dan Doa & Moderator \\
\hline 09:15 - 09:30 & $\begin{array}{l}\text { Sambutan perwakilan Pesantren Yatim } \\
\text { Cahaya Madinah }\end{array}$ & $\begin{array}{l}\text { Pesantren Yatim Cahaya } \\
\text { Madinah }\end{array}$ \\
\hline 09:30 - 09:45 & Sambutan Ketua PKM & Dyanda Ayundasari \\
\hline 09:45 - 10:00 & Sambutan perwakilan Universitas Pamulang & Chandra F. Arifianto \\
\hline 10:00 - 10:30 & Materi I: Pengenalan Nilai-nilai Pancasila & Dedek Putra Bungsu \\
\hline 10:30 - 11:00 & $\begin{array}{l}\text { Materi 2: Pengamalan Nilai-nilai Pancasila } \\
\text { melalui KOPALA (Komik Pancasila) }\end{array}$ & Pety Tanjung Sari \\
\hline 11:00 - 12:00 & ISHOMA & Moderator \\
\hline 12:00- 12:30 & Permainan & Moderator \\
\hline
\end{tabular}


Penanaman Nilai-Nilai Pancasila dengan Media Komik Pancasila (KOPALA) di Pesantren Yatim Cahaya Madinah Tangerang

Dyana Ayundasari, Aulia Rahmah, Dedek Putra Bungsu, Feri Agustiawan, Pety Tanjung Sari, Chandra Fitra Arifianto

Vol. 1, No. 2, Agustus 2021 hal. 116-122

DOI Artikel : 10.46306/jub.v1i2.22

\begin{tabular}{|l|l|l|}
\hline 12:30 - 13:30 & $\begin{array}{l}\text { Materi 3: Implementasi Nilai-nilai Pancasila } \\
\text { dalam kehidupan sehari-hari (Diskusi) }\end{array}$ & Aulia Rahmah \\
\hline 13:30 - 14:00 & Pemberian Donasi & Dyanda Ayundasari \\
\hline 14:00 - 14:15 & Penutup dan doa & Moderator \\
\hline
\end{tabular}

Tabel I : Rincian Acara Pelaksanaan Kegiatan

\section{Komik Pancasila (KOPALA)}

Komik Pancasila atau lebih dikenal sebagai KOPALA merupakan luaran dari salah satu Program Kreativitas Mahasiswa yang didanai oleh DIKTI. Tujuan kemunculan KOPALA ini adalah berkeinginan untuk menanamkan kembali nilai-nilai Pancasila yang dirasa hilang pada sosok generasi muda. KOPALA ini sendiri mulai dikenal di tahun 2013.

Fikriyah dkk. (2014) menjabarkan bahwa nilai-nilai yang ada kelima sila dalam Pancasila, tergambarkan pada KOPALA tersebut (lihat gambar 2). Saat ini sudah lima seri komik yang telah diterbitkan, dimana terdapat 10-17 halaman per serinya. Cerita yang diangkat menggambarkan pengamalan nilai-nilai Pancasila yang disertai dengan sila dan butirnya. Bahkan komik ini sudah tersedia secara daring (dapat diunduh maupun dibeli pada lokapasar). Yusri dkk. (2013) meyakini bahwa KOPALA ini dapat dijadikan sebagai alternatif media dalam menyampaikan nilai-nilai Pancasila pada generasi muda, terlebih anak-anak.

Atas pertimbangan itulah, tim PKM memberikan materi dengan memanfaatkan KOPALA yang memang sudah tersedia. Hanya saja ternyata para peserta tidak mengetahui tentang adanya KOPALA tersebut. Tampilan gambar dalam sangat menarik perhatian peserta karena memang tampilan sudah menggunakan warna secara keseluruhan. Selain itu, kalimat yang dipakai sangat mudah dicerna oleh peserta.

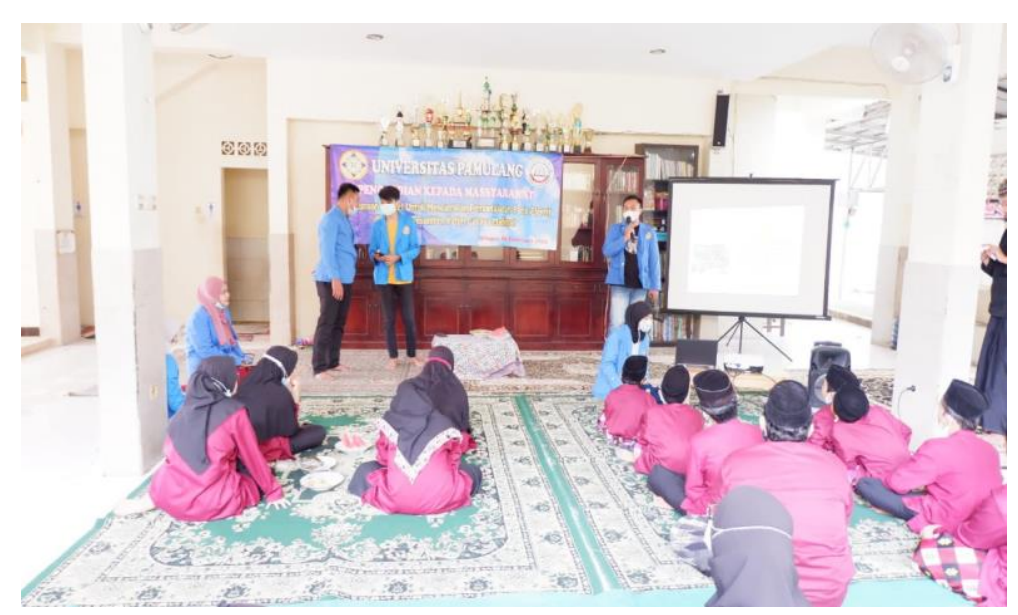

Gambar I : Pemberian materi oleh tim PKM 
Penanaman Nilai-Nilai Pancasila dengan Media Komik Pancasila (KOPALA) di Pesantren Yatim Cahaya Madinah Tangerang

Dyana Ayundasari, Aulia Rahmah, Dedek Putra Bungsu, Feri Agustiawan, Pety Tanjung Sari, Chandra Fitra Arifianto Vol. 1, No. 2, Agustus 2021 hal. 116-122

DOI Artikel : 10.46306/jub.v1i2.22

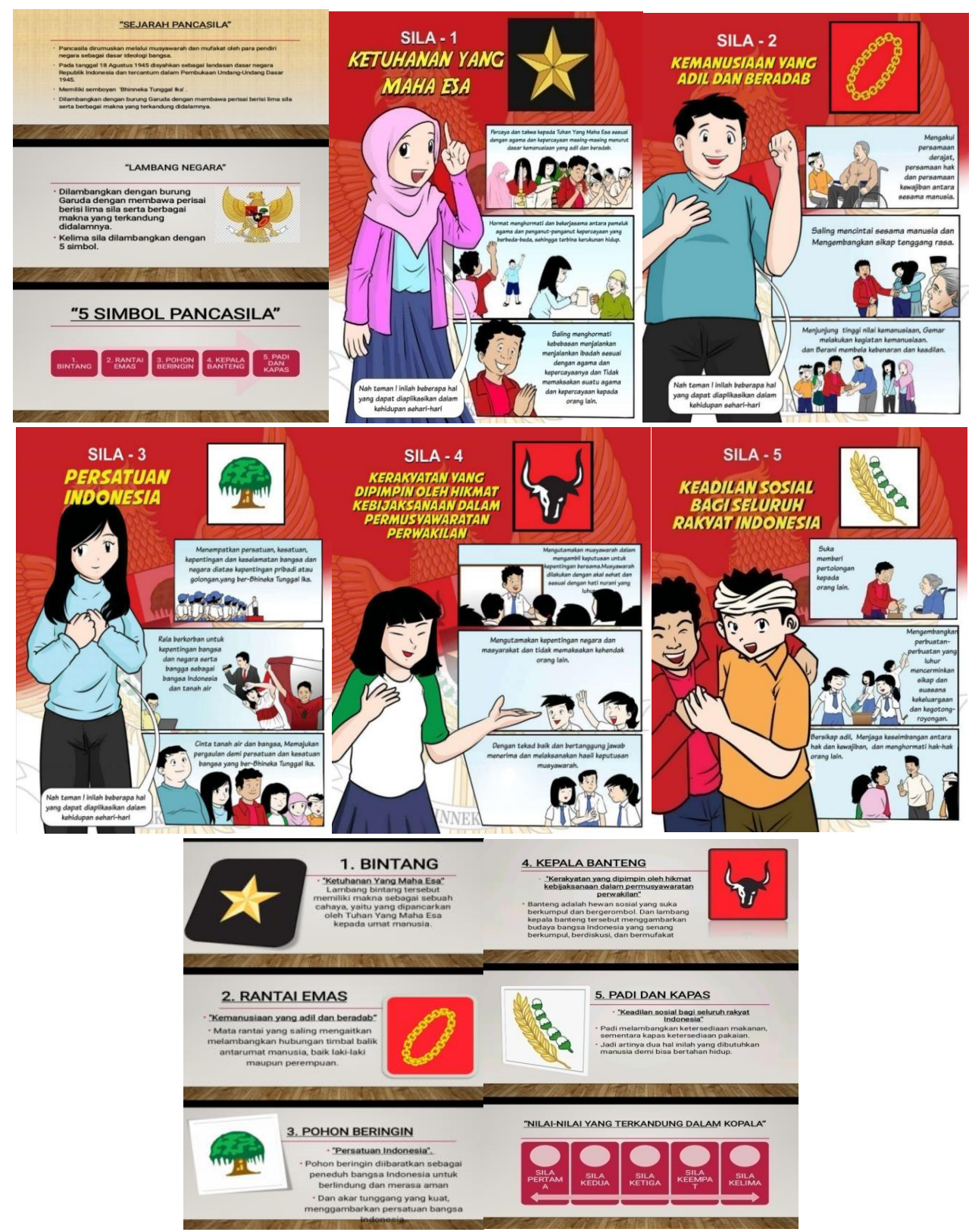

Gambar 2 : Tampilan Komik Pancasila

Saat sesi diskusi, tim PKM sengaja menggunakan media permainan sebagai metode untuk mengevaluasi keberhasilan pemberian materi tadi. Meskipun terlihat rileks, Budiman dkk. (2019) mengingatkan belum tentu secara kognitif mengena dan masuk ke dalam pikiran peserta didik. Berdasarkan observasi yang dilakukan, semua peserta nampak senang dan mau untuk turut terlibat dalam permainan (lihat gambar 3). Ini pertanda positif bahwa telah terjalin hubungan antara tim PKM dengan peserta. Di sela-sela permainan, ada beberapa pertanyaan yang diajukan oleh peserta yang langsung dijawab oleh para tim PKM secara bergiliran. Selanjutnya saat pertanyaan yang berbentuk evaluatif ditanyakan, para peserta saling berebut menjawab dan jawaban mereka selalu tepat. Beberapa contoh pertanyaan yang ditanyakan, sebagai berikut:

I. Sebutkan kelima sila yang ada pada Pancasila?

2. Berikan contoh tindakan yang menunjukkan pengamalan sila ke-3? 
Penanaman Nilai-Nilai Pancasila dengan Media Komik Pancasila (KOPALA) di Pesantren Yatim Cahaya Madinah Tangerang

Dyana Ayundasari, Aulia Rahmah, Dedek Putra Bungsu, Feri Agustiawan, Pety Tanjung Sari, Chandra Fitra Arifianto

Vol. 1, No. 2, Agustus 2021 hal. 116-122

DOI Artikel : 10.46306/jub.v1i2.22

3. Ketika pengambilan keputusan, kita sering untuk melakukan diskusi atau musyawarah sebelumnya. Itu contoh dari pengamalan sila ke berapa? Bagaimana bunyinya?

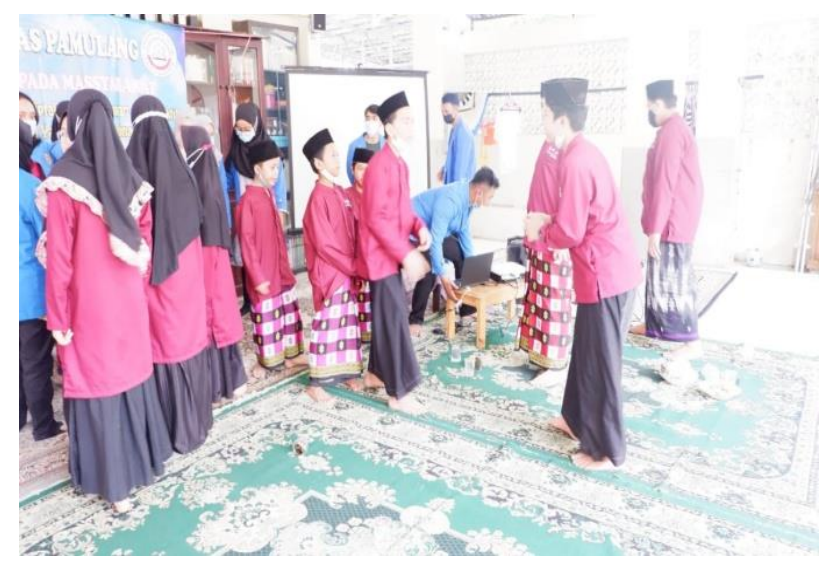

Gambar 3 : Suasana permainan berlangsung

\section{KESIMPULAN DAN SARAN}

Kegiatan PKM ini setidaknya dapat berjalan sesuai rencana dan walaupun ada beberapa kekurangan, kegiatan ini dapat terlaksana dengan baik. Segala kekurangan dapat tertutupi dengan antusiasme peserta dalam mengikuti setiap sesi yang diberikan. Dengan adanya kegiatan ini dapat diambil simpulan jika proses pembelajaran itu tidaklah mudah. Banyak hal yang perlu dipersiapkan secara matang. Terlebih pada aspek fasilitas dan materi.

Kegiatan ini juga dapat memberikan informasi bahwa metode pembelajaran visual dengan menggunakan media komik dapat dan mungkin untuk dipraktikkan. Pembelajaran menggunakan metode ini terlihat menyenangkan dan dapat dilakukan oleh siapapun, termasuk guru. Berdasarkan hasil evaluasipun menunjukkan jika peserta mampu menangkap materi yang diberikan.

Selanjutnya, perlu kiranya metode ini dapat dipraktikkan juga pada remaja dan dilihat juga kefektivannya. Tentu saja yang terpenting ialah peningkatan kapabilitas guru, baik dalam hal literasi, kemampuan menggunakan piranti lunak maupun keras, gawai, serta kompetensi sosial, termasuk manajemen kelas.

\section{UCAPAN TERIMA KASIH}

Teriring ucapan terima kasih kepada institusi kami, Universitas Pamulang atas dukungannya.

\section{DAFTAR PUSTAKA}

Budiman, J. Y., Sudjito, D. N., \& Maslebu, G. (2019). PENGGUNAAN PERMAINAN KARTU GEBRAK (KARAK) UNTUK EVALUASI PEMBELAJARAN FISIKA. Jurnal Sains dan Edukasi Sains, 2(I), 8-I5.

Fikriyah, A., Safitri, R. I., Afriyanti, A. F., Kristriana, O. W., \& Murti, C. (20I4). KOMIK PANCASILA (KOPALA): MEDIA PENDAMPINGAN PENANAMAN NILAI PANCASILA PADA GENERASI PENERUS BANGSA. Pekan Ilmiah Nasional Program Kreativitas Mahasiswa-Pengabdian Masyarakat. Kementerian Riset, Teknologi dan Pendidikan Tinggi.

Hendri, Darmawan, C., \& Halimi, M. (2018). PENANAMAN NILAI-NILAI PANCASILA PADA KEHIDUPAN SANTRI DI PONDOK PESANTREN. Jurnal Civics: Media Kajian Kewarganegaraan, I5(2), I03-II0. 
Khosiah, N. (2020). IMPLEMENTASI NILAI-NILAI PANCASILA PESERTA DIDIK DI MADRASAH IBTIDAIYAH MAMBAIL FALAH TONGAS-PROBOLINGGO. Jurnal Al-Insyiroh: Jurnal Studi Keislaman, 6(I), 84-100.

Mayanty, S., Rusmana, I. M.. \& Nurrahmah, A. (202I). STRATEGI MENJADI GURU INSPIRATIF DI MASA PANDEMI (PKM DI TK DAN SDI AL KAUTSAR BINTARO SCHOOL). Jubaedah: Jurnal Pengabdian dan Edukasi Sekolah, I(I), I-II.

Pujilestari, Y. \& Susila, A. (2020). PEMANFAATAN MEDIA VISUAL DALAM PEMBELAJARAN PENDIDIKAN PANCASILA DAN KEWARGANEGARAAN. Jurnal Ilmiah Mimbar Demokrasi, 19(2), 40-47.

Rafa'al, M. \& Sangadji, S. S. (2020). MERAWAT MODERASI BERAGAMA CERDAS BERMEDIA DI PONDOK PESANTREN HARISUL KHAIRAAT KELURAHAN OME KOTA KOTA TIDORE KEPULAUAN. Jurnal Abdimas Bina Bangsa, I (2), 223-230.

Savira, A. N., Fatmawati, R., Rozin Z., M., \& Eko S., M. (20I8). PENINGKATAN MINAT BELAJAR SISWA DENGAN MENGGUNAKAN METODE CERAMAH INTERAKTIF. Factor M, I ( I), 43-56.

Setiawan, Y., Kosasih, A., \& Komariah, S. (2015). POLA ADAPTASI SOSIAL BUDAYA KEHIDUPAN SANTRI PONDOK PESANTREN NURUL BAROKAH. Jurnal Sosietas, 5(I).

Yusri, Mudrika, \& Amin, A. A. (2013). KOMIK PANCASILA UNTUK GENERASI PANCASILA (IMPLEMENTASI NILAI PANCASILA MELALUI MEDIA KOMIK PADA ANAK USIA DINI). Jurnal Nalar Pendidikan, I (I), 5-I0. 